\title{
GL-1107
}

DOE/ID-97-01

\section{GEOTHERMAL HEAT PUMP BENCHMARKING REPORT}

\author{
DE-FG07-96ID 13466
}

January 17,1997

Prepared for

US Department of Energy

Idâho Operations Office

Prepared by

Today Associates

Syracuse, New York

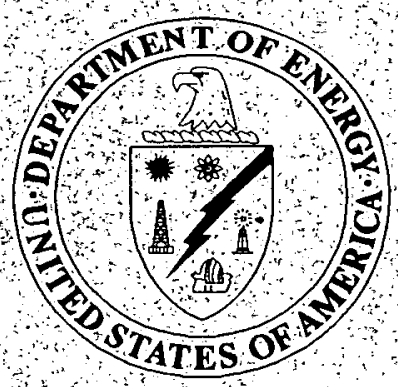




\section{DISCLAIMER}

This report was prepared as an account of work sponsored by an agency of the United States Government. Neither the United States Government nor any agency Thereof, nor any of their employees, makes any warranty, express or implied, or assumes any legal liability or responsibility for the accuracy, completeness, or usefulness of any information, apparatus, product, or process disclosed, or represents that its use would not infringe privately owned rights. Reference herein to any specific commercial product, process, or service by trade name, trademark, manufacturer, or otherwise does not necessarily constitute or imply its endorsement, recommendation, or favoring by the United States Government or any agency thereof. The views and opinions of authors expressed herein do not necessarily state or reflect those of the United States Government or any agency thereof. 


\section{DISCLAIMER}

Portions of this document may be illegible in electronic image products. Images are produced from the best available original document. 
s.

\section{DISCLAIMER}

This report was prepared as an account of work sponsored by an agency of the United States Government Neither the United States Government nór any agency thereof, nor any of their employees, makes any warranty express or implied or assumes any legal liability or responsibility for the accuracy, completeness, or túsefulness of any information, apparatús, product or process disclosed or represents that its use would not infringe privately owned rights. References herein to any specific commercial product process, or senice by trade name trademár manufacturer or othenwise, does not nésesarily constitüte or imply its endorsement recommendation or favoring by the United States Government or any agency therreof The viéws and opinions of authors expressed herein do not necessarily state or reflect those of the United States Government of any ágency thereof: 


\title{
GEOTHERMAL HEAT PUMP BENCHMARKING REPORT
}

\author{
DE-FG07-96ID13466
}

Submitted to the Department of Energy

Revised January 17, 1997 


\section{TABLE OF CONTENTS}

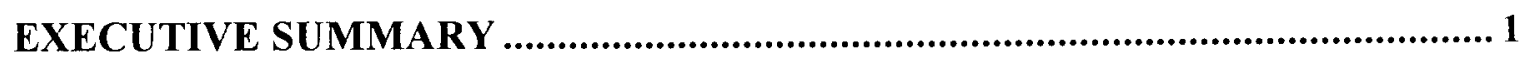

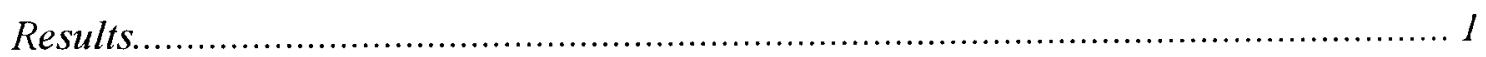

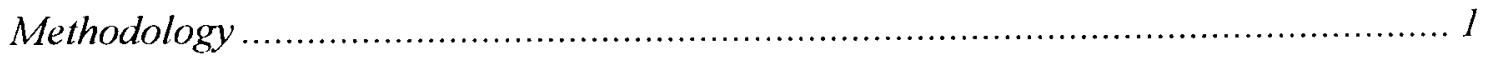

Successful Utility GHP Programs............................................................... I

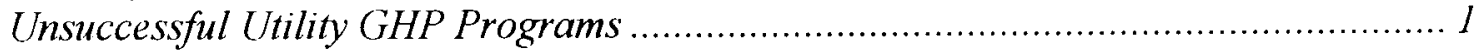

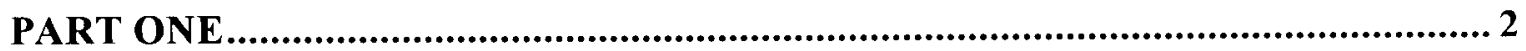

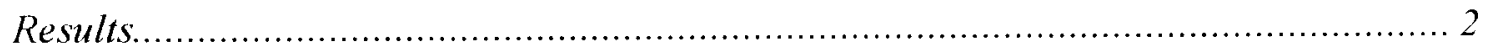

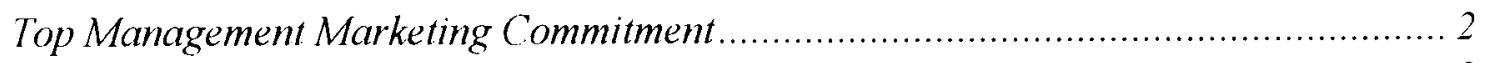

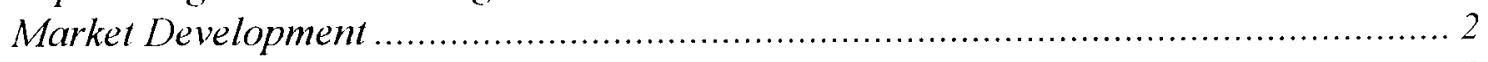

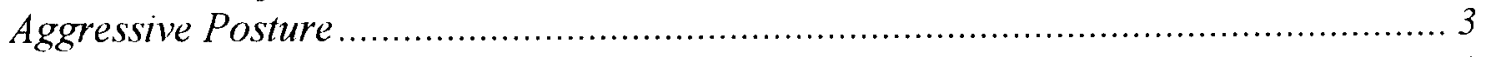

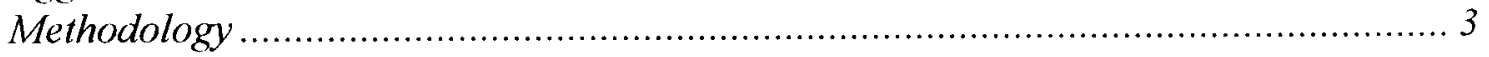

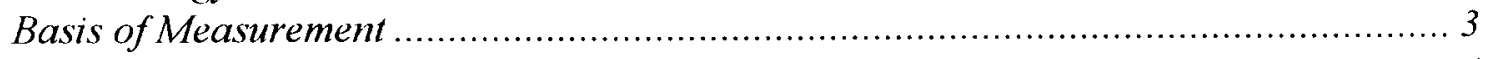

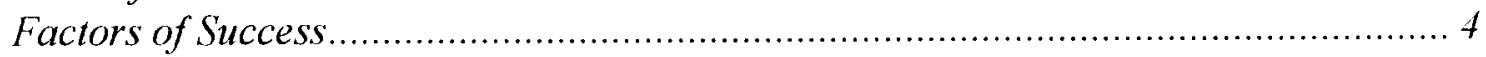

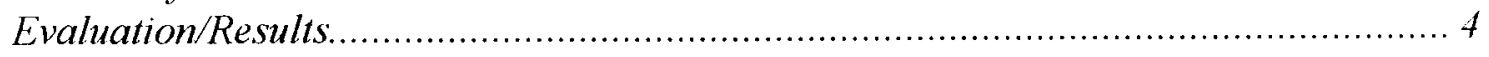

Interpretation

Problem Area

Explanation of Cultural Differences........................................................... 5

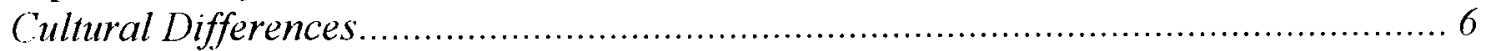

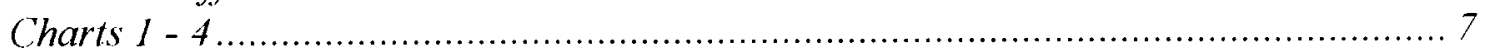

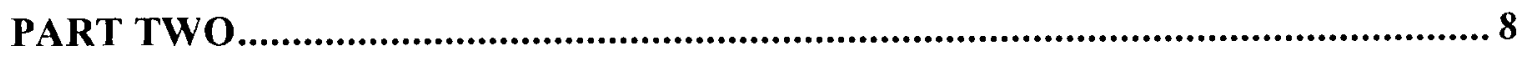

SUCCESSFUL GHP PROGRAMS ………………………

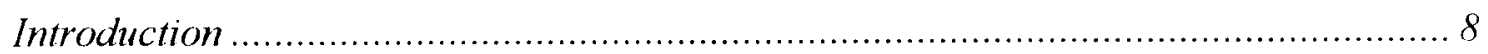

Successful Programs .............................................................................. 8

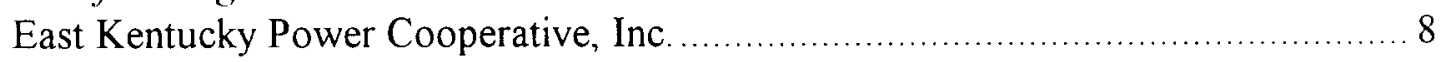

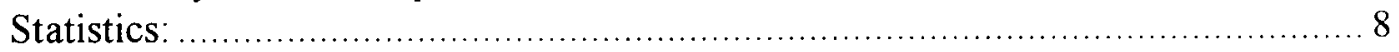

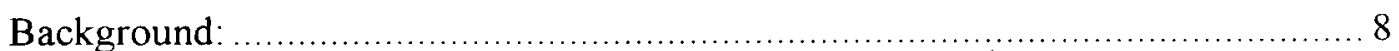

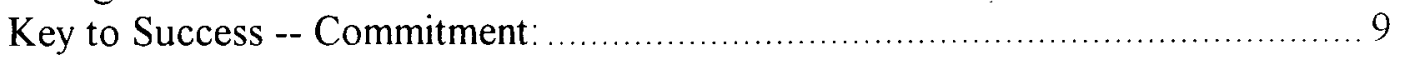

Market Development: ………………………

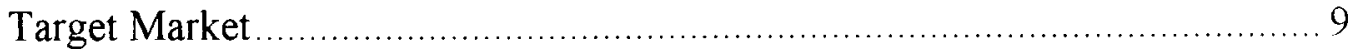

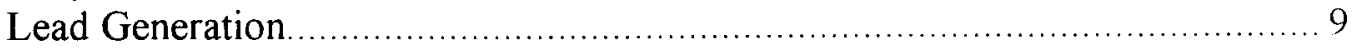

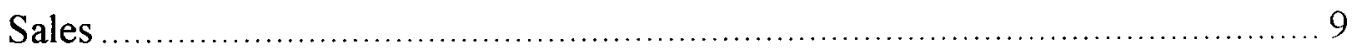

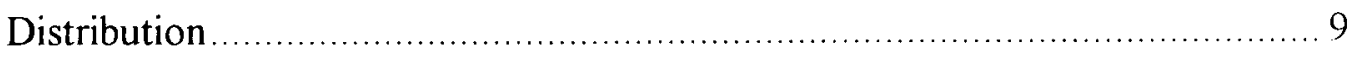

Red River Valley Rural Electric Association................................................... 10

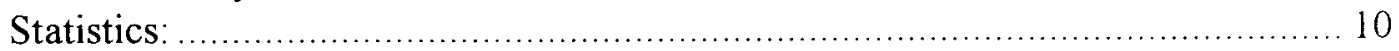

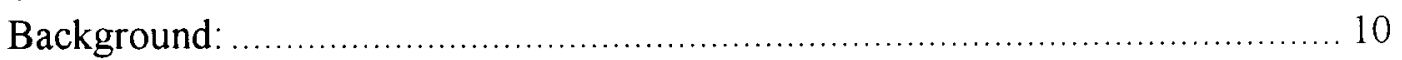

Key to Success -- Commitment: ............................................................. 10

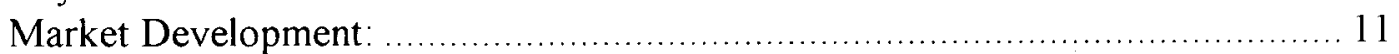

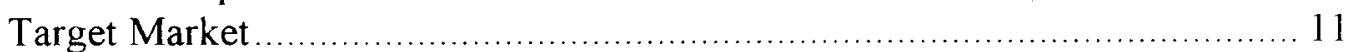

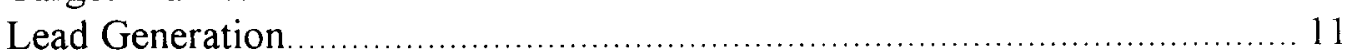

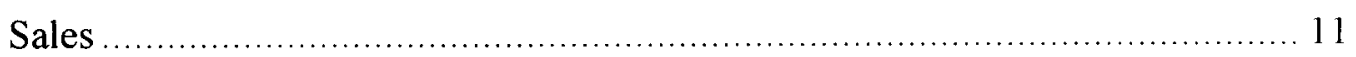

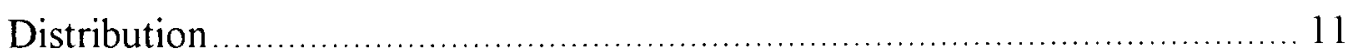

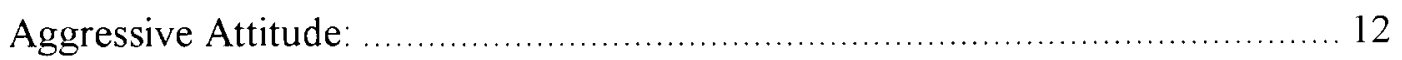

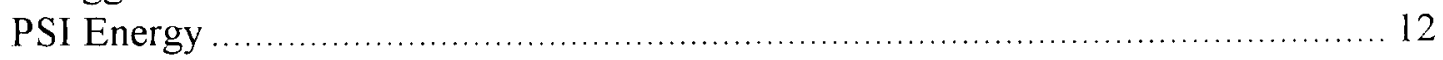

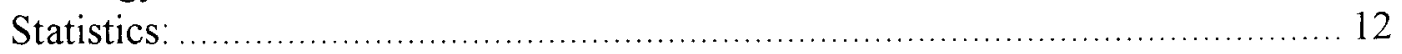

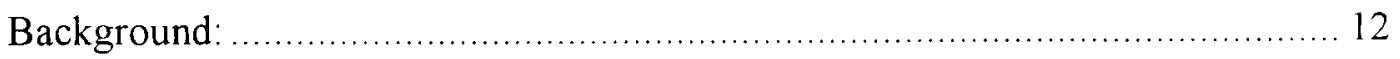




\section{TABLE OF CONTENTS}

Key to Success -- Professional, Comprehensive Market Development Program.. 12

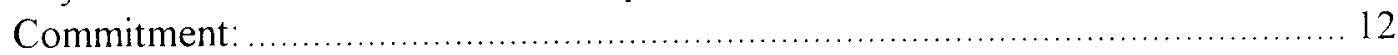

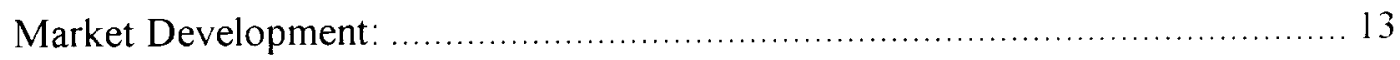

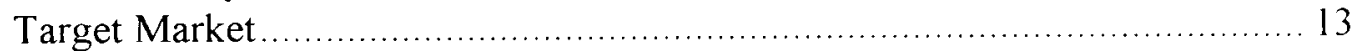

Lead Generation............................................................... 13

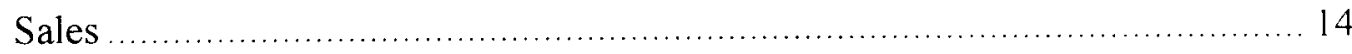

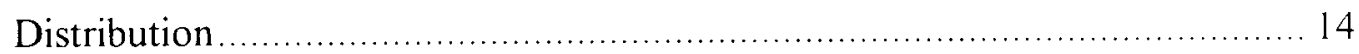

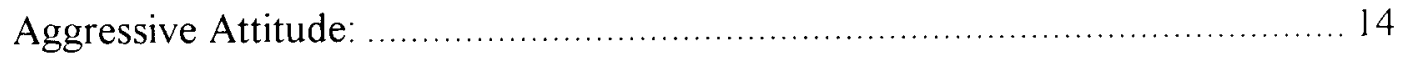

Consumers Power Corp ................................................................. 15

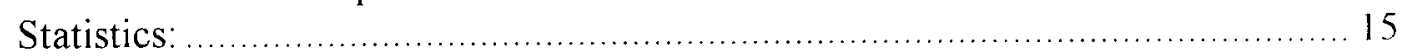

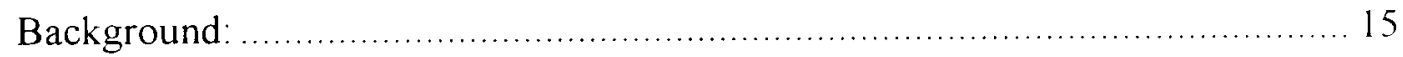

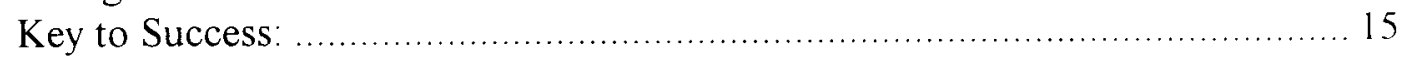

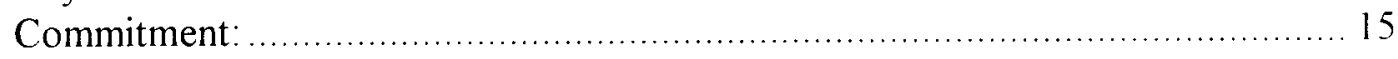

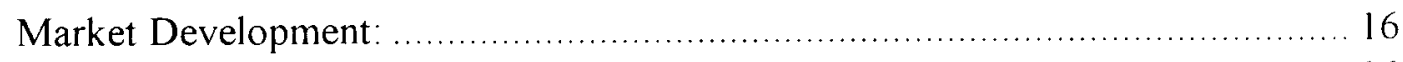

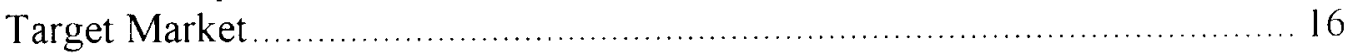

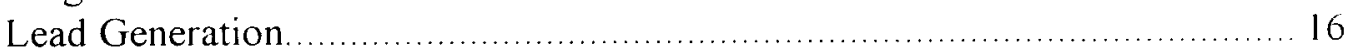

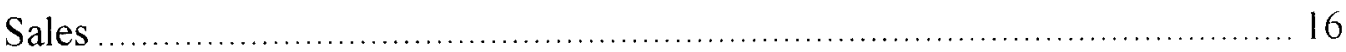

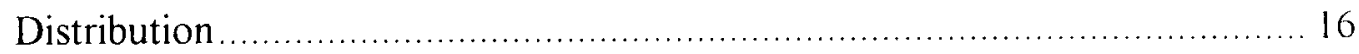

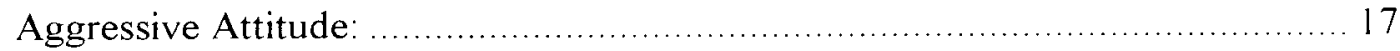

United Power Association............................................................... 17

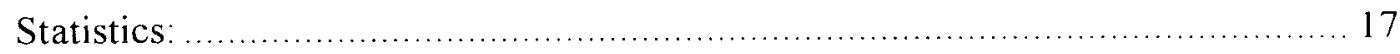

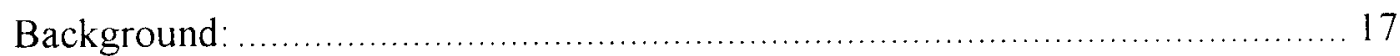

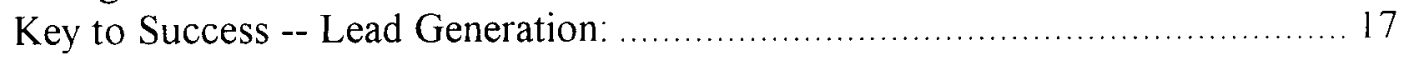

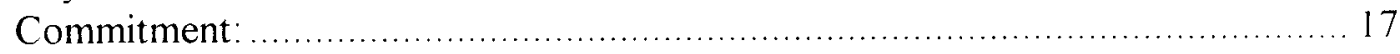

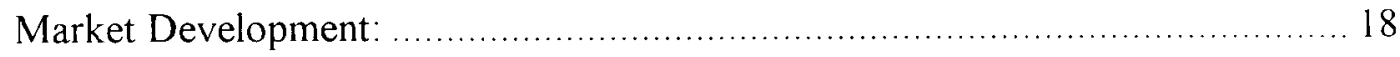

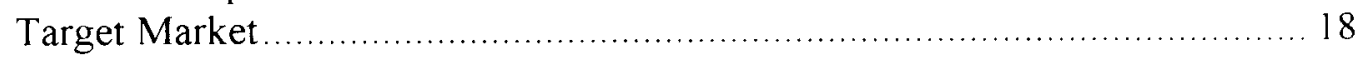

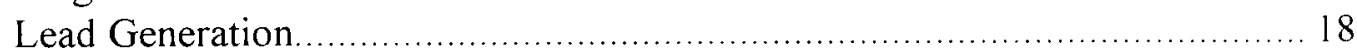

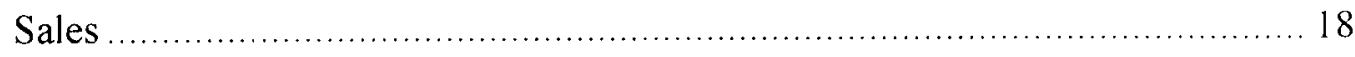

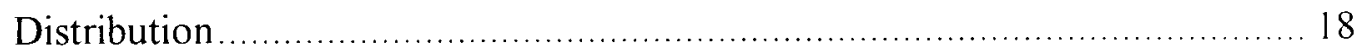

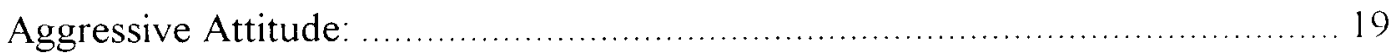

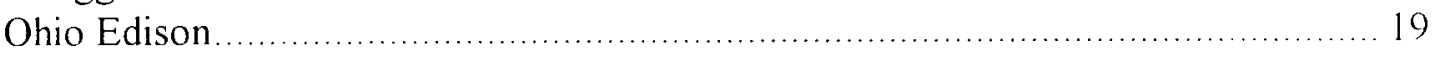

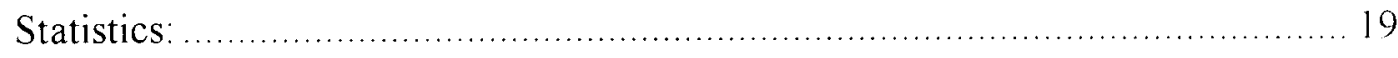

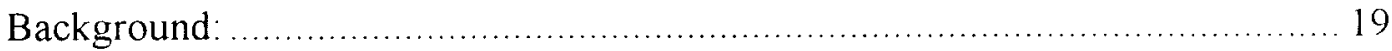

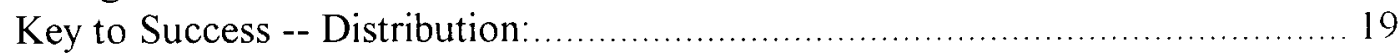

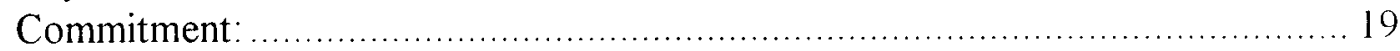

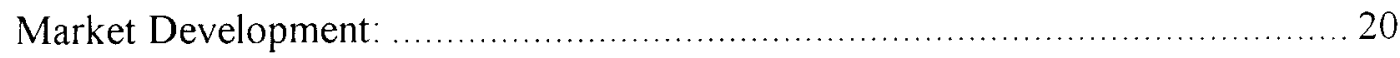

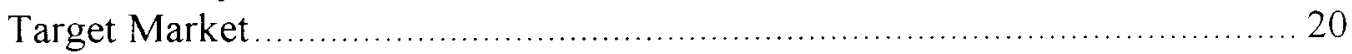

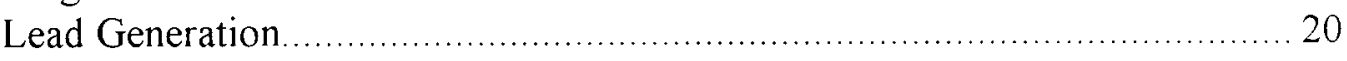

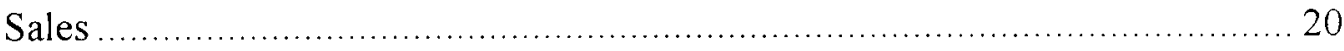

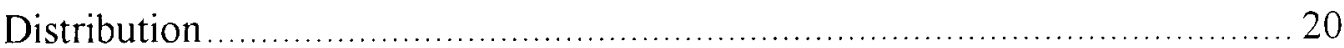

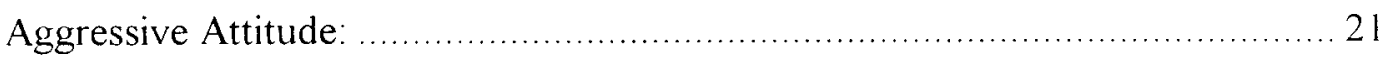

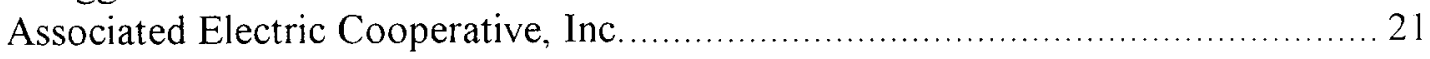

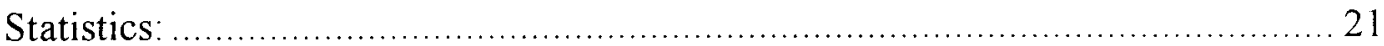

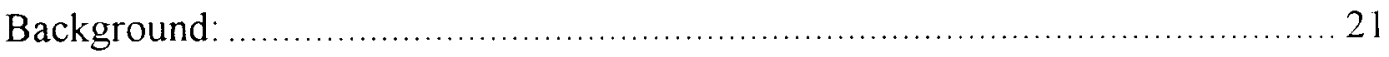

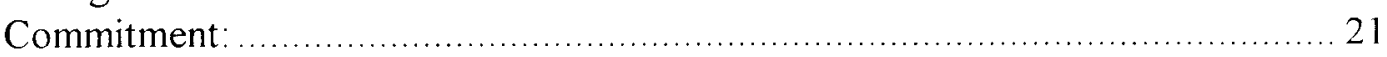

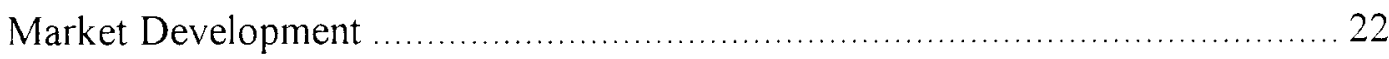

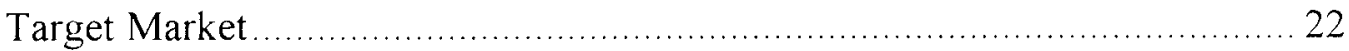

Lead Generation.................................................................... 22 


\section{TABLE OF CONTENTS}

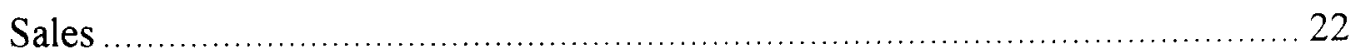

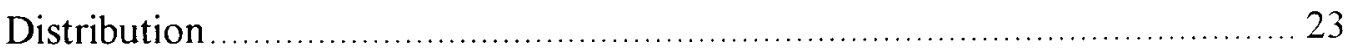

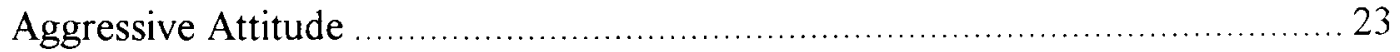

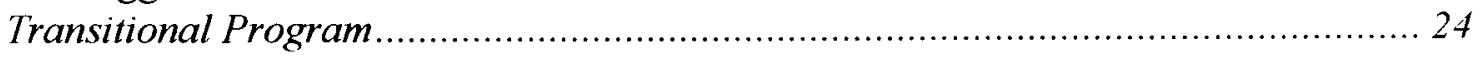

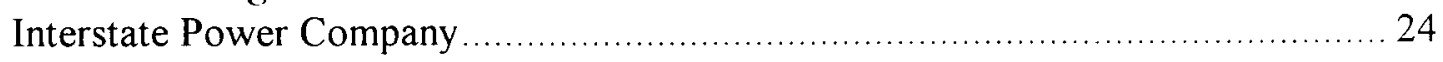

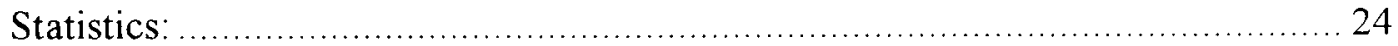

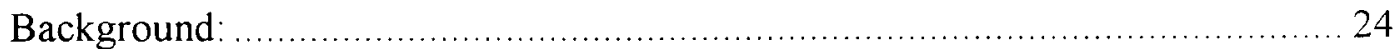

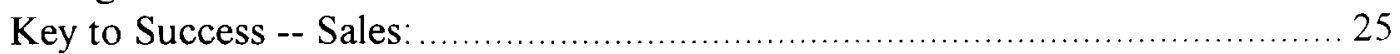

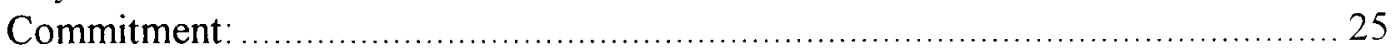

Market Development: .................................................................. 25

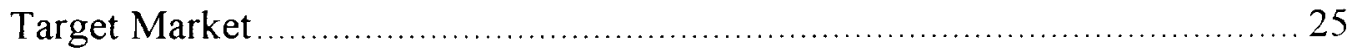

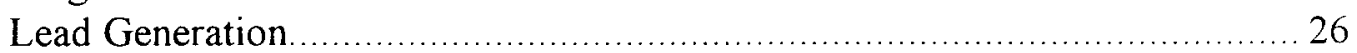

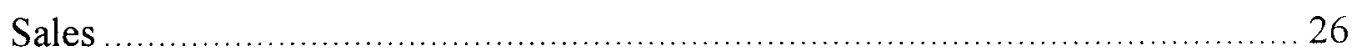

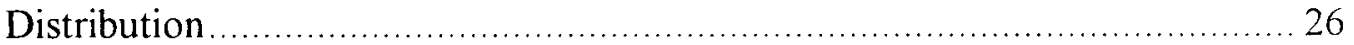

Aggressive Posture: ..................................................................... 27

Interpretations and Conclusions for Successful Utilities...................................... 27

What every GHP program needs to succeed ............................................ 27

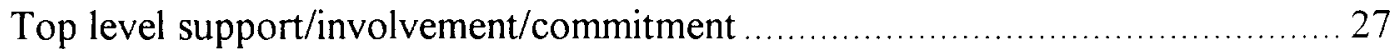

Comprehensive knowledge of market development and market development

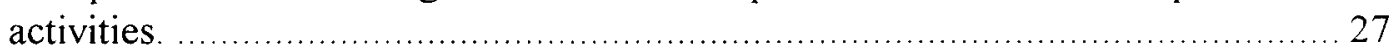

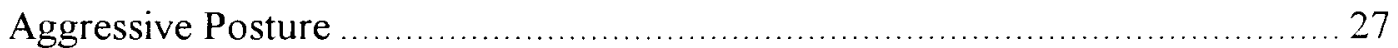

Utilities can get faster results with a professionally designed program................ 28

PSI \& Consumers Power ............................................................... 28

Utilities Can Succeed On Their Own ..................................................... 28

Obstacles encountered and solved by successful utilities are the types of obstacles encountered every day by companies in competitive environments..................... 28 Utilities can find that competitive "do whatever it takes" attitude -- look at their crisis

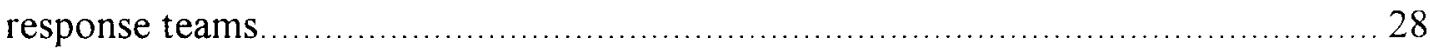

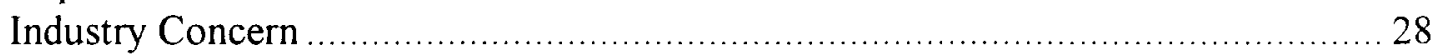

UNSUCCESSFUL GHP PROGRAMS................................................................. 29

How Unsuccessful Utilities can Enhance their GHP Programs and Produce Results. 29

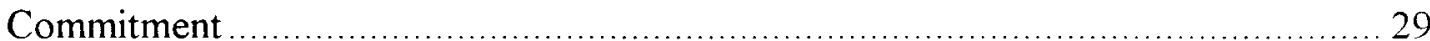

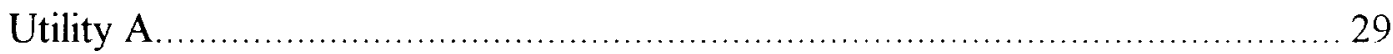

Recommendations ......................................................................... 30

Market Development -- Cohesive Strategy with Target Market .......................... 31

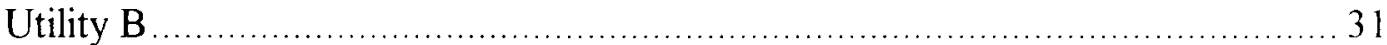

Market Development -- Lead Generation .................................................. 31

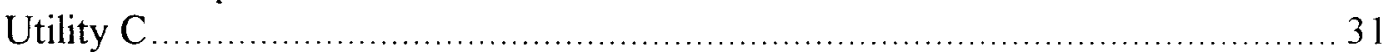

Market Development -- Sales................................................................ 32

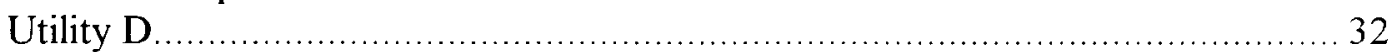

Market Development -- Distribution ...................................................... 33

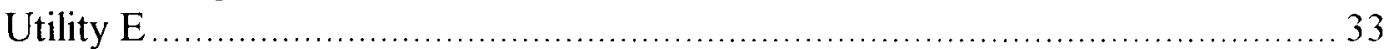

Interpretations and Conchusions for Insuccessful Utilities.................................. 34

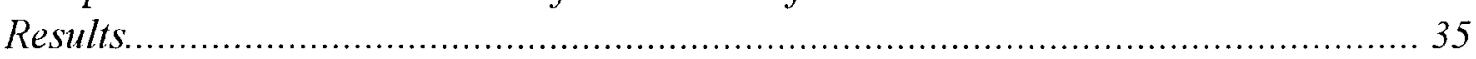




\section{Executive Summary}

A benchmarking study was conducted on behalf of the Department of Energy to determine the critical factors in successful utility geothermal heat pump programs. A Successful program is one that has achieved significant market penetration.

\section{Results}

Successfully marketing geothermal heat pumps has presented some major challenges to the utility industry, however select utilities have developed programs that generate significant GHP sales. This benchmarking study concludes that there are three factors critical to the success of utility GHP marking programs:

- Top management marketing commitment

- An understanding of the fundamentals of marketing and business development

- An aggressive competitive posture

To generate significant GHP sales, competitive market forces must by used. However, because utilities have functioned only in a regulated arena, these companies and their leaders are unschooled in competitive business practices. Therefore, a lack of experience coupled with an intrinsically non-competitive culture yields an industry environment that impedes the generation of significant GHP sales in many, but not all, utilities.

\section{Methodology}

This study focuses on twenty utilities that were divided into two groups, successful and unsuccessful, based on the number of GHP installations they achieved in relation to the size of their target markets

Each utility was evaluated through a combination of on-site interviews, telephone interviews and surveys.

\section{Successful Utility GHP Programs}

The data compiled on GHP programs identified as successful clearly demonstrates that all of these utilities had top management commitment, a comprehensive market development effort and an aggressive market posture.

\section{Unsuccessful Utility GHP Programs}

The data compiled on utility GHP programs classified as unsuccessful clearly demonstrates that lack of top management commitment is the major contributing factor to unsuccessful programs 


\section{Part One}

\section{Results}

Successfully marketing and selling geothermal heat pumps is not a major difficulty in and of itself -- however, it does present some major challenges to the electric utility industry.

Our study concludes that the factors critical to success are:

- Top management marketing commitment

- An understanding of the fundamentals of marketing and business development

- An aggressive competitive posture

\section{Top Management Marketing Commitment}

In a competitive environment, commitment is demonstrated through actions and behaviors. It is established on an individual basis, through personal accountability and responsibility for producing sales and results. This type of attitude and behavior permeates the entire corporation, fosters accountability, and has a direct impact on the products produced and programs created. Commitment comes from the top down. The personal involvement of upper management and marketing management will direct the action of the entire corporation and focus all actions on producing results

\section{Market Development}

Market development includes a sound understanding of the industry and key players, a well-developed strategy for breaking into target markets, and the development of appropriate market awareness and sales tools for each target market. Success is measured by sales.

There are three basic elements of market development:

1. Lead Generation -- this involves creating awareness and interest in a product or service then providing the means for customers to call or write for more information. Lead generation methods may include advertising (tv, radio, billboard, etc.), public relations campaigns, promotional pieces, trade and consumer shows, and more.

2. Sales Management -- this consists of converting leads into sales. This is achieved through personal sales calls, HVAC contractor networks, price management, and more. 
3. Effective Distribution -- critical to the success of any marketing program, distribution involves establishing long-term program support. methods of enforcing quality standards, and more.

Each of these elements -- lead generation, sales management, and effective distribution -are interrelated; that is, one cannot work without the other

\section{Aggressive Posture}

In a competitive environment, the motivation of all marketing is to increase sales, and/or market share. Management in competitive corporations recognize that the market is finite and other companies are vying for the same customers. As a result, they are constantly evaluating their position and the competition and changing to the dynamic marketplace. All action is focused on the results of getting customers and sales, and if the action isn't working or achieving results, it is changed. This overriding purpose of generating sales permeates the entire corporation and becomes part of its corporate culture. The approach is do what it takes to get sales

\section{Methodology}

To compile this report TODAY Associates first assembled a list of utilities that had conducted GHP programs. From this group we selected twenty utilities on which to focus our research. This group of twenty included utilities that we knew had been successful in achieving results (sales) and utilities that had been less successful or unsuccessful in achieving results (sales). Each of these utility programs was evaluated through a combination of on-site interviews, telephone interviews and surveys.

TODAY Associates also drew on data from the following:

- 35 IOU GHP programs conducted 1988-1992

- Hagler Bailly Benchmarking study

- TODAY Associates' first hand market development experience

\section{Basis of Measurement}

The twenty utilities were divided into two groups, successful and unsuccessful, based on the number of GHP installations they achieved in relation to the size of their target market.

Successful utilities are those that recorded significant mumbers of GHP installations in relation to the size of their markets and achieved meaningful market penetration. Unsuccessful utilities are those that had an insignificant 
number of GHP installations within their markets and achieved little market penetration.

\section{Factors of Success}

A detailed list of GHP program elements was compiled based on the activities identified to us by the successful utilities. (See checklist - Chart 1)

TODAY Associates then categorized these elements into three major areas, or factors of success:

- Commitment

- Market Development

- Aggressive Posture

These three factors are common to competitive marketing practices.

\section{Evaluation/Results}

We then evaluated all twenty utilities to determine the presence or absence of the factors of success. The results clearly show that for successful utilities all three factors are present. The individual elements within each factor may vary but all factors are present.

For unsuccessful utilities, the results are just as clear. All unsuccessful utilities stated there was no commitment by top management. All but one unsuccessful utility had a partial market development effort. Most unsuccessful utilities described their approach to the market as passive

\section{Interpretation}

Why has GHP marketing represented such a difficulty to so many utilities for so long?

The knowledge and experience required for successful market development is not present in most utilities.

Itilities can only be successful marketing GHPs if they adopt methods used by competitive industry.

How did successful utilities acquire the knowledge and experience necessary to sell GHPs?

They used one of two methods: 
1. They brought in the expertise.

2. They learned by trial and error over many years

\section{Problem Area}

Unschooled in competitive business practices, utilities have often struggled as they ventured into the competitive market development arena of GHPs. When they have been faced with marketing failure, rather than recognizing the problem as a lack of experience in marketing, they have often mistakenly focused on irrelevant issues: i.e. rebates, gas competition, front end cost, different training programs, loop design, different drilling methods, electric rates, financing, loop leasing, market research, etc., etc.

This problem can be overcome and has been overcome by utilities that adopt a competitive mindset and embrace all three factors necessary for success.

\section{Explanation of Cultural Differences}

For most of this century electric utilities have dedicated themselves to providing reliable electric service to their customers. The complexities of competition and competitive marketing were not integral to utility business practices, and as a result, the current skills and expertise of most utility personnel reflect the singular, service-oriented perspective.

Unfortunately, this puts utilities at a disadvantage in the competitive arena and in implementing competition based marketing programs. Competition demands a different set of skills and way of thinking.

By examining the three factors critical to success in GHP programs we will clarify the cultural difference between utilities and competitive industry.

These factors have one meaning for competitive industry and successful GHP utilities and a very different meaning for unsuccessful GHP utilities. 


\section{Cultural Differences}

\section{COMPETITIVE ENVIRONMENT}

Commitment - A type of attitude that is demonstrated through actions and behaviors. It is established on an individual basis, through personal accountability and responsibility for producing sales and results

Market Development - A set of activities that are designed to promote a product or service and increase sales, profits, and/or market share. Includes the following elements: 1) target market, 2) lead generation, 3) sales systems 4) distribution. If one element is left out, the activities will not achieve results. Market Development includes a sound understanding of the industry and key players, a well-developed strategy for breaking into target markets with a specific product, and the development of appropriate market awareness and sales tools for each target market. Success is measured by sales.

Aggressive Posture - The attitude that ensues from a sense of purpose. In this environment, it is derived from the motivation to increase sales, and/or market share. Aggressive behavior is demonstrated by constant evaluation of competition and subsequent change. All actions are focused on achieving results. If the action doesn't achieve results, it is changed. The company assumes total responsibility for developing the market.

\section{TRADITIONAL UTILITY}

Commitment - A type of attitude that is demonstrated through the allocation of resources -- how much money and manpower is earmarked for a certain project. There is no relationship between personal activities and performance in the marketplace, so there is no personal accountability for results

Market Development - A set of activities randomly chosen without an overall concept. These activities do not necessarily include knowledge of the market, a cohesive strategy for breaking into the market, an attempt to solve marketing problems, or any correlation between marketing and sales.

Success is often measured by the simple fact that activities occurred and resources were allocated.

Passive Posture - The expectation is that some entity other than the utility is or will be responsible for results in the marketplace. 


\section{GHP PROGRAM ELEMENTS CHECKLIST}

\section{COMMITMENT}

Top management actively involver

$\square$ Company education and awarentss program

- Employee support program

- Employee purchase program

$\square$ Top management has GHPs in their own home
AGGRESSIVE POSTURE

Willing to do whatever it takes!

Strong evidence of:

Commitment

Market Development

$\square$ Overall aggressive attitude

$\square$ Project Manager/Champion

\section{MARKET DEVELOPMENT}

\section{Lead Generation}

Direct Mail

$800 \#$

TV Ads

0 Radio Ad

Newspaper Ads

Billboards

- Home Shows

Mall Booths

Promotion program

Promotion materials

Bill Inserts

Newsletters
Sales

Lead Management Program

Lead follow-up

$\square$ Utilities sell or pre-sell GHPs

C Create competition

$\square$ Sales training

[ Sales incentives

$\square$ Sales goals

$\checkmark$ Key influencer program

\section{Distribution}

[] Recruit contractors

$\square$ Train contractors

¿ Support contractors

$\square$ Inspection Control

- Set and enforce standards

\section{TARGET MARKET}

$\square$ Residential retrofit and single new home

$\square$ Residential Builder/Developer Subdivision

c Commercial 


\section{SUCCESSFUL UTILITY TARGET MARKETS AND INSTALLATIONS}

\begin{tabular}{|c|c|c|c|c|c|c|c|c|}
\hline Utility & E. Kentucky & Red River & Ohio Edison & PSI & $\begin{array}{c}\text { Consumers } \\
\text { Power }\end{array}$ & $\begin{array}{l}\text { Associated } \\
\text { Electric }\end{array}$ & Interstate & United Power \\
\hline \multicolumn{9}{|c|}{ Customer Base } \\
\hline Totals & 360,000 & 8.353 members & $1.2 \mathrm{M}$ & 500,000 & $1.3 \mathrm{M}$ & 530.000 & 162.431 & $\sim 210,600$ \\
\hline $\begin{array}{l}\text { Target Market } \\
\text { Residential } \\
\text { New Housing } \\
\text { Commercial } \\
\text { Industrial }\end{array}$ & $\begin{array}{c}\text { Residential } \\
280.000\end{array}$ & $\begin{array}{c}\text { Residential } \\
6,300\end{array}$ & Res \& Comm & $\begin{array}{c}\text { New Housing } \\
6.000\end{array}$ & $\begin{array}{l}\text { Retrofit } \\
300,000\end{array}$ & $\begin{array}{c}\text { Residential } \\
477,000\end{array}$ & $\begin{array}{c}\text { Res \& Comm } \\
130.643 \\
\\
30,860 \\
928\end{array}$ & $\begin{array}{c}\text { Res }>\text { Comm } \\
\sim 195,000 \\
\sim 15,600\end{array}$ \\
\hline \multicolumn{7}{|c|}{ Residential Installations } & Combined & Combined \\
\hline Totals & $500 /$ year & 560 & $600 /$ year & 4,600 & $\sim 4,356$ & $10,000(\# 4)$ & Res \& Comm & Res \& Comm \\
\hline $\begin{array}{c}1996 \text { (est) } \\
1995 \\
1994 \\
1993 \\
1992 \\
1991\end{array}$ & $\# 7$ & $\begin{array}{c}24 \\
30 \\
26 \\
33 \\
29 \\
382(\text { Note \#1) }\end{array}$ & $\# 7$ & $\begin{array}{c}173 \\
168 \\
600 \\
600 \\
600(\# 2)\end{array}$ & $\begin{array}{c}580 * \\
550-600 / y r \\
550-600 / y r \\
550-600 / y r \\
2,126(\# 3)\end{array}$ & $\begin{array}{c}928(\# 8) \\
763 \\
1827 \\
1125 \\
1344 \\
1025\end{array}$ & \begin{tabular}{|c|}
$400(\mathrm{t})$ to date \\
$204(\mathrm{t})$ \\
$98(\mathrm{t})$ \\
$50(\mathrm{t})$ \\
$40(\mathrm{t})$ \\
$29(\mathrm{t})$ \\
\end{tabular} & $\begin{array}{c}795(\mathrm{t}) \\
460(\mathrm{t}) \\
1694(\mathrm{t})(\# 5) \\
1578(\mathrm{t})(\# 5) \\
530(\mathrm{t}) \\
505(\mathrm{t})(\# 6)\end{array}$ \\
\hline
\end{tabular}

Notes:

(1): installations in tons

$\sim$ : approximate

$>$ : moving towards

1996 installations are estimated through vear end unless otherwise noted

* Of the 580 installations, 460 were dealer influence and 120 were utility influenced

\#1: Total installations from 1984-1996 = 560 represents an $8 \%$ market penetration.

\#2: Total within the first 18 months of the program was 1.105 and from 1989-1993 PSI had 600/year. Program discontinued in 1993. PSI also installed 600 tons of commercial GHPs

\#3. Over the first three years, 1989-1991, of Consumers program 2,126 units were installed. Program discontinued in 1992. however, contractors have continued market expansion.

\#4: Total installations since 1986

\#5: During 1993 and 1994 United Power sold to 60\% of schools in their territory

\#6: Total residential, schools and commercial installations 1991 and prior.

\#7: Preferred not to give annual numbers.

\#8: Numbers in this block represent installation rebates. One rebate can include more than one GHP 


\section{OVERVIEW OF SUCCESSFUL UTILITY GHP PROGRAMS}

\begin{tabular}{|c|c|c|c|c|c|}
\hline Utility & $\begin{array}{l}\text { Management } \\
\text { Commitment }\end{array}$ & Market Development & Aggressive & $\begin{array}{c}\text { Target Market } \\
\text { and Size }\end{array}$ & Total \# Installations \\
\hline United Power & Yes & Comprehensive & Aggressive & $\begin{array}{c}\text { Residential }=\sim 195,000 \\
\text { moving towards } \\
\text { Commercial }=\sim 15,600\end{array}$ & $\begin{array}{l}804 \text { Residential and 3000(t) } \\
\text { Commercial since 1991 }\end{array}$ \\
\hline East Kentucky & Yes & Comprehensive & Aggressive & Residential $=280,000$ & 500 per year \\
\hline Red River & Yes & Comprehensive & Aggressive & Residential $=6,300$ & 560 since 1984 \\
\hline Ohio Edison & Yes & $\begin{array}{c}\text { Comprehensive } \\
\text { HIGHLY STRATEGIC }\end{array}$ & Aggressive & $\begin{array}{c}\text { Residential and Commercial } \\
1.2 \mathrm{M} \text { customer base }\end{array}$ & 600 per year \\
\hline Interstate Power & Yes & Comprehensive & $\begin{array}{c}\text { Aggressive } \\
\text { HIGHLY STRATEGIC }\end{array}$ & $\begin{array}{c}\text { Residential }=130,643 \text { and } \\
\text { Commercial }=30,860\end{array}$ & $821(t)$ \\
\hline PSI Energy & Yes & Comprehensive & Agressive & $\begin{array}{c}\text { New construction subdivision. } \\
6000 \text { new homes market }\end{array}$ & $\sim 4600$ over seven year period \\
\hline $\begin{array}{l}\text { Consumers } \\
\text { Power }\end{array}$ & Yes & Comprehensive & Aggressive & $\begin{array}{l}\text { Rural oil, propane retrofit } \\
\text { market. } 300,000 \text { households } \\
\text { in the state of Michigan. }\end{array}$ & $\sim 4356$ over seven year period \\
\hline $\begin{array}{l}\text { Associated } \\
\text { Electric }\end{array}$ & Yes & Comprehensive & Aggressive & Residential $=477,000$ & $\sim 10,000$ since 1986 \\
\hline
\end{tabular}

Comprehensive market development programs include effective lead generation, sales and distribution practices.

Partial market development programs have one or more practices absent from their program.

Aggressive describes a utility that will take complete responsibility and do whatever it takes to ensure sales.

Passive describes that utility program in which there is no accountability for results.

These utilities are Case Studies and it is noted that other successful programs exist. These utilities serve as Benchmarks for all successful utility programs. 
OVERVIEW OF UNSUCCESSFUL UTILITY GHP PROGRAMS

\begin{tabular}{|c|c|c|c|c|c|c|c|c|}
\hline Utility & $\begin{array}{c}\text { Management } \\
\text { Commitment }\end{array}$ & \multicolumn{4}{|c|}{ Market Development } & Aggressive & $\begin{array}{c}\text { Target Market } \\
\text { and Size }\end{array}$ & Total \# Installations \\
\hline & & Lead Generation & Sales & Distribution & Overall & & & \\
\hline A & No & Yes & None & Yes & Partial & Aggressive & $\begin{array}{c}\text { Residential }=200,000 \\
\text { \& Commercial }= \\
45,000^{*}\end{array}$ & $\begin{array}{c}50^{*} \text { for the past three } \\
\text { years }\end{array}$ \\
\hline B & No & Yes & Yes & Yes & Comprehensive & Passive & Commercial $=261,188^{*}$ & $\sim 175^{*}$ since 1993 \\
\hline C & No & No & Yes & No & Partial & None & Residential & $20^{*}$ \\
\hline D & No & Yes & Yes & No & Partial & Very Passive & None & Confidential \\
\hline E & No & No & Yes & No & Partial & Passive & Residential and & $\sim 150^{*}$ \\
\hline
\end{tabular}

*The figures above have been changed to protect those parties involved.

Comprehensive market development programs include effective lead generation, sales and distribution practices.

Partial market development programs have one or more practices absent from their program.

Aggressive describes a utility that will take complete responsibility and do whatever it takes to ensure sales.

Passive describes that utility program in which there is no accountability for results. 


\title{
Part Two
}

\author{
Successful GHP Programs
}

\section{Introduction}

Geothermal heat pumps require utilities to act in a manner that is completely opposite their nature. The geothermal heat pump is a replacement product going into a $100 \%$ saturated market. There is not a single building in the country that will go without heat if it does not have a geothermal heat pump. GHPs are not necessary to satisfy the marketplace demand for heating and cooling. Plus, GHPs are not well known, so marketing programs created for them must be the most competitive programs in the HVAC industry. Therefore, marketing GHPs requires an aggressive behavior pattern that is completely opposite the one to which utilities are accustomed. In this sense, GHPs will be a very effective tool for transporting utilities into the competitive marketplace.

\section{Successful Programs}

To illustrate the mindset and culture of a successful utility, we will describe the programs of several utilities that achieved a significant market penetration with GHPs (note: market share is the ratio between sales and the number of customers within the specific target market). This accounts for differences among utilities with a smaller customer base or a highly targeted market. Again, we have selected these utilities based on the evaluation of the industry, the competitive marketplace, and quantitative data. These utilities are case studies and it is noted that other successful programs exist. Eight programs have been chosen as benchmarks for successful programs. They contain all three factors of successful programs: commitment, market development, and aggressive posture.

\section{East Kentucky Power Cooperative, Inc.}

Winchester, Kentucky

\section{Statistics:}

East Kentucky Power installs 500 three ton equivalent units per year

\section{Background:}

East Kentucky Power is a generation and transmission company with 18 district co-ops. They serve 280,000 residential customers. Its GHP Program began 10 years ago as an attempt to reduce peak demand. Based on a rates impact test, the utility saves $3 \mathrm{kwh}$ in the winter and $.9 \mathrm{kwh}$ in the summer because of GHPs, for a total savings of $10 \mathrm{MW}$. 


\section{Key to Success -- Commitment:}

East Kentucky Power is an excellent example of top level management commitment. In 1986, the CEO of the utility installed a GHP in his house. For the next five years, he tracked the system's performance and reported the savings to the Board of Directors every month. As a result of his records and recommendations, 13 members of the board (there were 18 total), including the Chairman of the Board and the Vice Treasurer, installed GHPs in their homes.

At the employee level, some district co-ops offer incentives if employees wish to purchase and install GHPs for their homes. Incentives are available for ARI 325 listed GHPs.

\section{Market Development:}

\section{Target Market}

East Kentucky Power decided to target the residential market because $68 \%$ of their customer base is residential.

\section{Lead Generation}

The utility used television, radio and print advertising to initiate the program and generate interest. Then they evaluated the program participants demographically and changed their incentives based on those evaluations to better target the marketing program. The utility's research showed that a large percentage of GHP buyers were owners of large homes (four ton capacity) and had higher income levels. Based on this information, East Kentucky Power decided to change their rebate offer from $\$ 500$ per system in retrofit and $\$ 1,000$ per system in new to $\$ 165$ per ton in retrofit and $\$ 330$ per ton in new (R38 ceiling, R28 walls, R19 floor). They also tailored their advertising messages to meet the needs of customers in specific areas (for example, new home market in urban areas).

\section{Sales}

East Kentucky's GHP Program was designed to have the co-ops act as the sales force, which would receive support from the six person marketing team at the utility. This approach has been successful in the commercial market as well as the residential market -- it resulted in GHP installations in five schools within the service territory and 15 schools statewide.

\section{Distribution}

To gain the involvement of HVAC contractors, East Kentucky advertised the GHP marketing/business opportunity in several trade magazines. 
To generate interest and excitement among HVAC contractors, builders and architects, East Kentucky hosts an Energy Management Conference every January before the new building season begins. The utility picks up all expenses and brings in speakers who are well versed on a variety of topics that are of interest to the group. The Energy Management Conference is well attended -- every year it attracts between 425 and 550 individuals. This conference generates excitement before the "new building season."

To ensure quality installations, East Kentucky Power offered classroom training for HVAC contractors and joined with the University of Kentucky in 1992 to offer IGSHPA certification classes for loop installers (certification includes training in fusion and installation).

East Kentucky tries to be "accessible to the installer." They believe in a team effort. To facilitate installations, they maintain a database of HVAC contractors and loop installers who are committed to the technology.

\section{Red River Valley Rural Electric Association}

Marietta, Oklahoma

\section{Statistics:}

Red River Valley has installed 560 GHPs since 1984. Because of these installations, the load factor has improved from $38.17 \%$ in the early eighties to $52.57 \%$ in 1995 . Saving the cooperative about $\$ 500,000$ annually in demand charges. This savings is a benefit to all Red River Valley customers, saving about $\$ 100$ for each customer, not just the ones who installed GHPs.

\section{Background:}

Red River Valley has a customer base of 8,353 , of which 6,300 are residential. The utility GHP Program was started in 1984 in order to increase the load factor and manage demand. Roughly $70 \%$ of GHP installations are retrofit homes and $30 \%$ are new homes. The utility is summer peaking.

\section{Key to Success -- Commitment:}

Red River Valley's GHP Program started because three managers took it upon themselves to learn about GHPs. These three individuals went to Oklahoma State University (OSU) to learn about the technology, and they were so convinced of its benefits that they had GHPs installed in their own homes.

This type of personal commitment to the technology permeates the entire utility. Many managers and board members have GHPs in their homes, all five people in the marketing department have GHPs in their homes. 


\section{Market Development:}

\section{Target Market}

Residential retrofit market.

\section{Lead Generation}

The utility originally used a variety of media to generate interest in the product. As the program grew and became more well-known, Red River focused on using newsletters, literature, and word of mouth advertising for educating the consumers.

Ninety-eight percent of the people who purchased GHPs from Red River Valley said they would recommend a GHP to their friends, based on a survey they conducted regarding customer satisfaction. Ninety-seven percent said they were given accurate information about the performance of their GHP and $97 \%$ said they would buy a GHP again.

\section{Sales}

Red River Valley's GHP Program is directed by the board members and employees. They are in tune with consumer demand and make changes to the program when necessary. For instance, in March 1986, the utility had several problems when they tried to retrofit the waste heat recovery system to old water heaters (especially propane water heaters) because of calcium buildup. In response to this problem, utility executives developed a program to install new water heaters that suspended calcium. For owners of GHPs, these water heaters provided a way to heat their water for free. Customers without GHPs could also take advantage of this program. By jumping on this opportunity, Red River was able to sell and install 4,000 water heaters.

Another example of how utility personnel devised creative ways to increase revenue through the GHP Program is the Loan Program. The Loan Program made it possible for members to purchase GHPs directly from the co-op and finance the purchase at $8 \%$ over five years. The repayment of these loans has increased the utility's revenue by $\$ 102,000$ to date.

The utility also created a subsidiary called Earth Energy Technology and Supply because there was a demand for the utility's expertise. Earth Energy is a wholesale supplier of everything needed to install GHPs. It has 14 employees and annual sales of $\$ 4.2$ million. All profits are returned to Red River Valley.

\section{Distribution}

At the GHP Program's inception, Red River Valley invited local HVAC contractors to attend a seminar on GHPs. The utility also sent the contractors for training at OSU. Each contractor involved in the utility's GHP Program must meet the quality and price 
specifications established by the utility. If the specs are met, the utility will warranty the GHP under the Trane Warranty for 10 years.

By establishing these specifications, the utility can control the price and quality of GHP installations. The utility has between seven and nine contractors working with them full-time, and one contractor works under the utility $65-70 \%$ of the time.

\section{Aggressive Attitude:}

Red River Valley has a proactive, aggressive stance in the marketplace. As a result of their aggressive attitude, when they see opportunities, they are able to capitalize on them. This attitude produces results in the form of increased GHP sales and overall profits for the utility.

\section{PSI Energy}

Plainfield, Indiana

\section{Statistics:}

Within two years, PSI raised their market share in the target market from less than $3 \%$ to $22 \%$.

\section{Background:}

PSI's share of the home heating market in the fastest growing part of their territory (new housing subdivision market) dropped to below 3\%. Utility management wanted to reverse this trend, so they decided to promote GHPs as a way to gain market share.

\section{Key to Success -- Professional, Comprehensive Market Development Program} PSI's program was developed because their share of the new housing market in one county that represented $50 \%$ of all new houses in their territory dropped to less than $3 \%$. The CEO wanted to try GHPs as a way to compete head-to-head with gas company for market share.

\section{Commitment:}

The Vice President of Marketing, Director of Marketing, and the Director of Residential Marketing all were personally involved in the GHP Program on a regular basis. They worked together to support the plan development and implementation. They were personally involved in the program and interacted regularly with all company marketing and sales personnel regarding the GHP program. A lot of effort went into the development of the internal part of the GHP program to make sure the employees were aware and supportive of the GHP effort. 
To demonstrate the extent of the personal commitment on the part of PSI, the CEO put a GHP in his home and assigned direct responsibility for the GHP program to the Vice President of Marketing, a person who had the leverage and authority to enlist the support of utility personnel and make results happen in the marketplace.

\section{Market Development:}

The Vice President of Marketing's personal background was introducing new products into the marketplace (in a competitive company), so when he was charged with the task of figuring out a way to successfully compete, he supported approaches similar to what he learned in competitive corporations. He also brought in outside expertise to help put together a professional market development effort. This effort was similar to ones implemented in competitive environments.

PSI took total responsibility for developing the marketplace and involving all key players in the industry. The utility orchestrated and directed the entire effort, which included market research, brand naming, pilot programs, test marketing programs, and extensive organization of the GHP industry. Some of the results of this project include the development of the International Ground Source Heat Pump Association (IGSHPA), the first annual IGSHPA Conference, and demonstration programs sponsored by the Electric Power Research Institute (EPRI).

Every element of PSI's program contained a mechanism for evaluation so it could be monitored and refined.

\section{Target Market}

New home construction market, subdivisions.

Commercial - was not a target market but PSI achieved excellent results in this market. A total of 13 commercial installations were sold, including a 300 ton office building. A focus of the commercial effort was to test the commercial market and understand how to develop it. It was clear that the projects had to either be sold by the utility or specified by architects and engineers. Basically, we learned the utility had two choices: 1) identify repetitive types of commercial installations (schools) that the utility could sell (and gain economics of scale for marketing/sales costs and engineering design and installation costs) or, 2) develop a committed architect and engineer infrastructure that specified GHPs on a wide scale (and thereby create economics of scale through common use and competitive bidding).

\section{Lead Generation}

PSI used all common advertising media -- including radio, TV, print, direct mail, inserts, billboards. The materials educated customers on GHPs, made them aware of the utility's efforts to promote GHPs and generated leads for PSI. PSI developed a trademark name, System $G T$, and a competitive industry marketing program. 


\begin{abstract}
Sales
Management and market development consultants met one-on-one with utility sales representatives to see how things were going and assist them in any way possible. They provided sales training, went out on sales calls with field representatives, and developed strategies to effectively sell builders and contractors on the technology. They also developed a strategy to use GHPs to sell all-electric homes.
\end{abstract}

PSI marketing management and sales representatives personally sold developers on allgeothermal subdivisions. PSI paid for and supervised loop installations. The loop payment program was done on an investment basis to guarantee $100 \%$ all-electric subdivisions; the non-GHP revenue (hot water, range, dryer) more than justified the cost of the loop. The average cost of loops (horizontal and vertical) was $\$ 1,600.00$ based on volume contracts with loop contractors. Homeowners were provided with a comfort guarantee which provided for PSI to fix the systems (if necessary) to satisfy the customer.

Loops were provided only in all-electric, all GHP subdivisions.

\title{
Distribution
}

PSI met with manufacturers and suppliers to involve them in all levels of the GHP efforts to help reduce the cost. PSI worked with manufacturers and suppliers to facilitate volume sales at the consumer end to reduce the price of loop installation. They did this by getting developers and builders to commit to large volumes of GHP installations (buying in bulk reduces the price per unit).

\section{Aggressive Attitude:}

PSI's GHP Program was designed specifically to go after new construction markets in order to increase market share. The program was extremely aggressive -- the utility advertised that "Geothermal heat was superior to gas." Projects were sold to create allelectric subdivisions -- sharing was not an option. PSI took total responsibility to develop the GHP market. 


\section{Consumers Power Corp.}

Jackson, Michigan

\section{Statistics:}

The target market was less than 300,000 households. It was estimated the actual HVAC market, retrofit and new was 12,000 units annually.

\section{Background:}

Consumers Power is a combination utility that has both electric and gas. They wanted to increase their electric load in non gas areas and decided the way to do it was through geothermal heat pumps.

Based on PSI's success with SystemGT, Consumers Power decided to buy the Program from PSI. Consumers Power was convinced the program would work and enable them to achieve faster results in the marketplace than if they established their own program from scratch.

\section{Key to Success:}

Professional, comprehensive market development plan (a proven winner).

\section{Commitment:}

The Director of Marketing for Consumers Power was completely involved in developing the GHP program. He had tremendous support from top level management and the latitude to make it work.

The Director of Marketing involved all the sales managers and marketing managers in the effort and conducted sales and sales management training programs that were designed specifically for the SystemGT program. Consumers Power was committed to the technology, and they were willing to experiment with innovative elements in their marketing department to initiate success in their marketplace.

One of the innovative elements they tried was an incentive/bonus system that was directly related to GHP sales. A percentage of the salaries of individuals in Consumers Power's marketing and sales department was based on their performance in the marketplace. 


\section{Market Development:}

\section{Target Market}

Propane and oil heat customers in rural upstate Michigan. The total number of these households for the state of Michigan was 300,000 in 1987. The number in

Consumers' territory was less than this. The exact number was not available.

\section{Lead Generation}

Same as PSI, except Consumers Power did not advertise on television. Efforts included education, awareness, direct mail, brochures, and bill inserts.

\section{Sales}

Same as PSI. Efforts included one-on-one selling.

Incentive - $\$ 50$ to HVAC contractor or distributor, $\$ 80$ per ton to homeowner.

\section{Distribution}

Efforts included development of contractor network, and recruiting of manufacturers and suppliers

Consumers Power's GHP program differed from PSI in one significant aspect.

Because the focus of the Consumer's program was the retrofit, one-at-a-time home market, developing a strong, committed, trained HVAC contractor and distribution network was key to program success. Marketing management and representatives worked closely with selected HVAC contractors to support them and assist them in ways that would both result in GHP installations and develop the HVAC contractors GHP business. A great deal of effort was invested in this part of the program.

Consumers Power recruited the most qualified, committed HVAC contractors in the area; trained them on correct installation techniques; showed them the tremendous opportunities that exist in the GHP market; gave them business support by teaching how to develop their business around GHPs; sent them enough leads to get them going, and made them dependent on GHPs. This way, the contractors would step up and promote GHPs themselves, or at least recommend GHPs to customers over other types of heating and cooling equipment. After four years, the GHP market continues to grow and thrive without the financial help of the utilities. (This program demonstrates the financial burden of promotion can be taken off utilities and taken up by HVAC contractors, who have the potential to reap the benefits of the GHP market). 


\section{Aggressive Attitude:}

Consumers Power's GHP program was extremely aggressive. The goal was to increase GHP market share. Consumers Power took total responsibility to do whatever it took to get results.

\section{United Power Association}

Elk River, Minnesota

\section{Statistics:}

United Power has installed over 3000 tons of GHPs in schools, banks, churches, commercial and industrial facilities. In the residential market, they have installed GHPs in 804 homes since the program began in 1991.

\section{Background:}

United Power began its GHP Program in 1991. They offered a special electric rate for homeowners and business owners who installed GHPs. Their motivation was to provide customers with a comfortable, low-cost heating and cooling system that competed with gas.

United Power is a generation transmission company with 12 distribution co-ops in its territory. The 12 co-ops distribute power to 195,000 residential customers and 15,600 commercial customers.

\section{Key to Success -- Lead Generation:}

For United Power, the key to success is educating the customers and putting in the time and hours to make sales happen. Marketing personnel attend school board meetings to present the concept of geothermal heat, involve themselves in all school decisions, and take school board members and superintendents on tours of schools that have GHPs. They sponsor conferences that target specific market segments.

\section{Commitment:}

United Power's GHP program has had the support of the General Manager from the start, and a personal commitment to GHPs permeates the entire utility. Every department cooperates to make GHP installations a reality. To help overcome the first cost price barrier, the utility offers low-interest financing to residential and commercial customers and provides incentives for customers and contractors. They also helped develop a slinky loop approach to loop installations to keep prices low.

United Power works hard to meet the special needs of its customers. For example, it provided the necessary financing to sell a 100 ton GHP system to a furniture store. The utility will even hire a consulting engineer to give an objective opinion to a building owner 
if the owner's own engineer is reluctant to try geothermal heat. This type of commitment is critical to the success of GHP programs.

\section{Market Development:}

\section{Target Market}

Originally residential but now moving into commercial.

\section{Lead Generation}

United Power's key to success is educating the customer. This is accomplished by participating in home shows and Home Buyer Workshops. The utility also sponsors special events to gain the interest of potential customers. For instance, one Saturday every spring, the utility will invite homeowners and buyers into the utility for a presentation on GHPs. The auditorium is usually full, because people trust the utility and listen to the information and ideas presented.

The utility hosts two 3-day workshops per year, one for home builders and one for electricians and HVAC contractors. Key people from each field are invited to attend, and the utility picks up the tab. The Home Builders Workshop allows builders and utility personnel to discuss issues that are important to new home construction and the commercial market and gives the utility a chance to introduce new products and services.

The workshop for electricians and HVAC contractors helps the utility develop and maintain a network of high quality contractors.

\section{Sales}

United Power originally targeted the residential market, but now they're moving more into the commercial market (i.e. schools, banks, churches). To do this, they plan to develop a new message and brochure, because the old one is aimed at builders, real estate agents and HVAC contractors. The utility also had a booth at an architect convention recently.

\section{Distribution}

Through its workshops, the utility has developed a network of trade allies, which consists of electricians and HVAC contractors. With the help of a GHP manufacturer, the utility trains the contractors on proper GHP installations using the slinky loop system. 


\section{Aggressive Attitude:}

United Power takes an aggressive stand in the promotion of GHPs by actively recruiting new members for its trade ally network and pursuing new commercial customers. The utility is nationally recognized for its Energy Thermal Storage (ETS) Program -- it has been distributing ETS products for over a decade

\section{Ohio Edison}

Akron, Ohio

\section{Statistics:}

Annual growth rate in GHPs since 1990: 45\% per year on the average.

\section{Background:}

Ohio Edison began tracking GHPs as a separate item in 1990 and took a strategic approach to developing that market since that time. Jeffrey Metcalf, Senior Market Analyst, took over the program three years ago.

Ohio Edison's customer base is 1.2 million. It is primarily residential, with high growth in the area of new construction. Eighty-eight percent of the market uses gas, and gas prices are highly competitive, but they are successfully persuading people to switch from relatively inexpensive gas service to GHPs by focusing their program on cost and comfort.

The purpose of Ohio Edison's GHP Program was strategic load growth and "a sense of urgency to become profitable" in the wake of deregulation.

\section{Key to Success -- Distribution:}

According to Metcalf, the key to Ohio Edison's success with GHPs is its excellent relationship with trade allies. Ohio Edison aggressively pursues contractors to become part of their dealer network, and they are actively involved in training the contractors. The utility's relationship with trade allies also enables them to overcome the first-cost price barrier.

\section{Commitment:}

The utility targets its own employees. Ohio Edison agreed to offer low-interest financing and other incentives to all employees who wished to install GHPs in their homes. This strategy was designed to encourage utility employees to not only use the product, but talk about its benefits with their families and friends.

Ohio Edison's commitment to GHPs comes from the top down. Many top level executives believe in the technology so much that they put it in their homes. Some of their field personnel and office staff also have GHPs in their homes. 


\section{Market Development:}

The success of Ohio Edison's market development activities is due to the fact that they understand the industry and the motivation of the key players (customers, contractors, loop installers). They educate the customer base on the benefits of the product and established guarantees that minimized the customer's risk, which results in lead generation. They developed an effective system for capturing and handling leads and following up until the job was completed, and they understand the concept of price control, service, quality and warranties.

\section{Target Market}

Residential

\section{Lead Generation}

To generate interest in GHPs in the residential market, the utility developed a targeted message that helped people overcome their fear of the unknown product by focusing on cost and comfort. To communicate the cost savings and comfort improvement of GHPs, Ohio Edison implemented two guarantees. The first one, the Comfort Guarantee, states that Ohio Edison will remove a GHP if a customers is unsatisfied with it for any reason. This takes the risk away from the consumer, holds the utility responsible, and gives the technology credibility. The utility also offers a Heating Cost Guarantee, which stipulates that a third party vendor will pay customers the difference between their actual heating cost and the promised heating cost if the GHP does not lower their heating bill to the promised level. With this guarantee, the customer will not lose.

\section{Sales}

To capture and track the leads, Ohio Edison established a toll-free 800 number. The utility uses the information obtained from the 800 number to chart demographic information and match customers with trade allies in their area (obtained from the contractor/loop installer tracking and mapping system). Customers are encouraged to call several contractors for quotes in order to keep the contractors competitive.

Ohio Edison implemented a quality survey that has been in place for the past 10 years. Utility representatives inspect jobs to make sure each installation is up to the high level of quality their program demands.

\section{Distribution}

Ohio Edison has over 300 contractors in their network. Ten contractors install more than 50 GHPs per year and one installs over 100 per year.

To recruit contractors and educate them on the benefits of GHPs, Ohio Edison hosts an annual conference, which is attended by more than 370 contractors. They then 
track dealers and loop installers and map them demographically in order to facilitate installations and make decisions regarding infrastructure needs. This tracking and mapping system enables the utility to match customers with contractors and loop installers -- Ohio Edison will give customers the names of several trade allies in their area and suggest they call for quotes on the job. This aggressive strategy helps contractors remain competitive and keep the price of GHPs down. It also requires careful management of contractor relationships in order to maintain control of market forces.

To train the contractors in efficient methods of installation that meet the established standards of quality, Ohio Edison requires all contractors to work with manufacturers and distributors during their first few installations. Manufacturers and distributors can show contractors ways to expedite installations and maintain a high level of productivity, which helps to keep costs down.

They understand the motivating forces behind the efforts of HVAC contractors, manufacturers and loop installers, and they work with each party to educate, train, and provide support in order to ensure the success of the program.

\section{Aggressive Attitude:}

Ohio Edison's creative approach to solving the first cost price barrier, their strategic approach to market development, and their active involvement with key players in the GHP industry, position them aggressively in the GHP market.

\section{Associated Electric Cooperative, Inc.}

Springfield, Missouri

\section{Statistics:}

AECl's system-wide marketing of GHPs began in 1986. The utility's customer base is 530,000 meters, and AECI has installed approximately 10,000 GHPs.

\section{Background:}

AECI supplies wholesale power to six regional G \& Ts who serve 43 local electric co-ops in Missouri and South East Iowa. They decided to market GHPs because they believed the technology was good for the utility and good for their members.

\section{Commitment:}

AECI's commitment comes from the top down. Several utility managers have GHPs in their homes and some of their co-ops are run by GHPs and utilized as demonstrations for customers. This commitment stems from their focus on the customer. The utility is 
actually owned by its customers (members), so it does not have a vested interest in selling products its members do not want.

The utility supports the GHP program economically and by DSM and technical assessment studies. It also gathers data on GHPs from manufacturers, other utilities, trade associations and government agencies to provide to its members.

\section{Market Development}

\section{Target Market}

Since $99 \%$ of the utility's customers are residential, their target market is residential. Two out of three GHPs they sell are installed in new construction homes.

\section{Lead Generation}

AECI has an internal promotion system for its employees, which includes Marketing Update, a monthly publication to keep Member Services personnel up-to-date on marketing activities. This helps maintain the enthusiasm and momentum for marketing programs and sales promotions.

To promote GHPs, AECI has implemented a long-term, unified marketing program called Marketing 2000, which includes print ads in local newspapers and trade publications, radio ads, brochures, fliers, and other promotional items. The utility does not advertise on television because they feel TV is generally not cost effective in their rural market.

AECI offers rebates of $\$ 250$ per ton. They have found the rebate acts as a cost equalizer versus other HVAC alternatives, and two out of three customers reported they would not have purchased a GHP without it.

The utility also conducts a promotion called "Cash in on Comfort," which is designed to prompt consumer requests for GHP information and generate leads for Member Services personnel.

\section{Sales}

AECI continuously trains its sales force and keeps them informed on GHP technology. The utility provides technical training and marketing support for Member Services personnel and implements sales incentives for its co-ops that are directly related to performance in the marketplace.

The utility has a toll free 800 number that customers can call for information. The number is connected to the Missouri Heat Pump Association. The association then 
refers customers to the local co-op. Co-ops will follow up by visiting the customers, referring them to an $\mathrm{HVAC}$ Contractor, or sending them literature.

To keep the overall GHP program on track, AECI conducts a Heat Pump Consumer Satisfaction Survey, which must be completed by the consumer in order to qualify for the rebate. The survey tracks customer satisfaction with GHP installation, operation and purchasing options. It also provides feedback on brands, reasons for purchase, sources of information, and demographics.

\section{Distribution}

AECI developed an effective network of trade allies through the Missouri Heat Pump Association. The association gives the utility access to competent, enthusiastic HVAC distributors, dealers and contractors. The utility also recruits loop installers (well drillers), because they have found that this group can "make or break" your GHP program. By developing trade allies, AECI can control the quality and price of installations. The utility keeps trade allies informed through a quarterly publication called Power Savvy. They also make trade allies key participants in seminars, training and sales promotions.

To help promote GHPs, AECI developed a network of builders, realtors, architects, and developers (through Homebuilders' Associations, IGSHPA and similar groups). The utility recognizes the builder is the one person who has the ability to influence the customer to purchase a GHP over other amenities. The builder also has the ability to decide on factors that are critical to optimum GHP performance, such as thermal envelope, insulation, ducting, and HVAC system sizing.

To effectively "sell" the builders on GHPs, AECI provides rebates and other financial incentives. For example, the utility runs a promotion called "Hammer Home the Savings," in which they invite builders to breakfast ("Hammers and Eggs") and encourage them to register for free trip to the Homebuilders Conference. During the breakfast, utility personnel provide information on GHPs and encourage GHP installations.

\section{Aggressive Attitude}

AECI has a very aggressive attitude. It is marketing oriented and supportive of marketing initiatives that directly benefit their members. 


\section{Transitional Program}

Interstate Power Company's GHP program demonstrates all three factors of success: commitment, market development, and aggressiveness, however, the number of tons installed do not translate into a significant market share

Interstate has focused efforts on high-profile commercial buildings and has met with success. This market approach can result in a high volume of installations if the infrastructure becomes the "target market." In order to maximize this effort, the utility must use those high-profile projects to educate and motivate the industry infrastructure (i.e. engineers and architects) so that the number of installations increases. Interstate must continue to develop its close relationship with engineering firms and architects to the point where the firms are committed to the technology and recommend it to their other clients.

\section{Interstate Power Company}

Dubuque, Iowa

\section{Statistics:}

The utility has installed GHPs in the county courthouse, the county office building, five corporate facilities, the community college, churches, apartment complexes, a funeral home and a restaurant.

\section{Background:}

Jim Walters, Manager of Residential and Commercial Services, is the Program Director for Interstate Power's GHP program. Jim is a former lineman who took the reins of the program in 1990 and brought the program to the forefront of the utility's initiatives through his commitment, focus, and energy.

The utility's initial motivation for this program was to manage load factors and sell electric heat. Now there is an understanding of the value of the GHP program in creating brand recognition for the utility to tap into as it enters a competitive market.

Interstate Power Company is comprised of six districts, each with its own Consumer Services Departments. The entire utility, from top management to the linemen, is actively involved in the program. In October 1991, the utility established an internal newsletter, SystemGT News, to update utility employees on the goals and status of the GHP marketing effort and motivate the district offices by publishing a list of the installations Additionally, each line crew is provided with a marketing book that describes the technology and benefits of GHPs so they could answer the questions of curious customers whom the line crew encounters as the work.

Interstate measures the success of its program by quantitative data. The utility sets high, yet concrete, goals for itself; the goal for this year is 840 tons. 


\section{Key to Success -- Sales:}

Interstate Power has the factors of a successful GHP program: icommitment, market development and an aggressive attitude. It has a solid understanding of the GHP market and market development and an excellent relationship with trade allies. Its success in the sales department is due to "one-on-one" selling. Its chosen target market, one-of-a-kind, high visibility commercial projects, requires "buy in" by the A and E firms in order to create volume.

\section{Commitment:}

The Program Manager's personal commitment to the technology is the basis for his commitment to the GHP program. His enthusiasm and commitment successfully captured the attention of Interstate's top management, who included the GHP program in long-term plans for the utility.

Interstate's management made the GHP program a central part of its first of six initiatives for the coming year. As stated in the company's 1995 Annual Report, the purpose of its first initiative is "to increase energy sales consistent with efficient energy usage." It goes on to report that "energy efficiency with increased comfort is being aggressively marketed through geothermal heating and cooling."

Interstate's top level management is behind the program one hundred percent. They give the Program Manager the latitude and support he needs to make decisions that drive the program forward. This commitment goes beyond words and permeates the entire utility. Interstate's Vice President of Electrical Engineering has installed a GHP in his home.

Management has invested resources into the program with the understanding that the goal is not short-term profit but rather long-term gain. The district offices are actively involved in generating leads, making the sales, and providing service follow-up after the sales. The utility's commitment is evident by the success it has seen.

\section{Market Development:}

\section{Target Market}

Interstate Power has a complete understanding of the GHP industry and all the available markets for GHPs. Its primary target market is large commercial buildings. This market has been chosen for a number of reasons, primarily for economies of scale. The utility's marketing efforts are clearly focused on influencing the decision markers for this market. (Caution: this target market will only produce big volume if the utility creates GHP committed engineering and architect firms).

The utility also recognizes the importance of finding the right combination of market development activities, which include lead generation, sales and distribution. 


\section{Lead Generation}

To generate interest in GHPs, Interstate works to create awareness on several levels. Internally, employees are updated on GHPs and the program through the internal newsletter, SystemGT News. Externally, line crews are given laminated books about the technology, how it works, and where to find dealers and loop installers, so they can answer questions for customers when they are in the field. The utility also developed brochures, videos, and a program called "The Choice of Excellence," which encourages customers to invest in energy efficient homes.

\section{Sales}

Interstate found that the key to closing the sale in the commercial market is "one-toone" marketing and relationship building. For instance, the Program Manager flew the engineers associated with a potential commercial installation to see a similar GHP operation in Indianapolis. He also flew with engineers to see a GHP operation in Canada. By devoting personal attention, using videos, and bringing engineers to see similar applications of the technology, the Program Manager is able to convince these key people in the importance, feasibility, and benefit of geothermal technology. $\mathrm{He}$ has also developed alliances with engineering firms.

When met with opposition from engineers, architects, and commercial builders, Interstate offers design services to demonstrate how to install and utilize GHPs. Interstate also offers follow-up service to guarantee satisfaction after the sale and installation is complete.

\section{Distribution}

Interstate Power works hard to influence and work with the trade allies who are crucial to the sale and installation of GHPs. By providing education to contractors and installers, Interstate builds relationship with these key groups. The utility has found that one-to-one relationship building is the key to facilitating the distribution of this technology through builders, engineers, and architects.

Interstate is especially dedicated to educating its trade allies about geothermal heating and cooling. In May 1996, Interstate Power Company, Northeast Iowa Community College, the Iowa Energy Center, and the Iowa Heat Pump Association hosted the Geothermal Heating and Cooling Symposium for 130 contractors, architects, engineers, installers, dealers, and homeowners.

Additionally, Interstate Power worked with Northeast Iowa Community College (NICC) and the Geothermal Heat Pump Consortium to spearhead a ten-course series on GHPs for contractors. This series is broadcast on the community college television network for contractors throughout Iowa. Interstate Power's Program Coordinator also coordinates regular GHPC satellite teleconferences on NICC's television network and teaches courses for installers at the college. 
Training for HVAC contractors is offered through South Dakota State University. Interstate firmly believes in educating the dealers who install GHPs and has established a program to pay the tuition for dealers to attend GHP training sessions.

\section{Aggressive Posture:}

Interstate is aggressive in its pursuit of additional commercial projects. Flying engineers to actually see GHPs at work, developing education programs to meet the needs of trade allies, involving the entire utility in the GHP marketing program, and working to meet the individual needs of customers are all tangible examples of the aggressiveness of Interstate's GHP marketing program. This aggressiveness is embodied in the program manager, whose commitment and focus on results drives the program forward. The Program Manager aggressively courts trade allies and pursues large-scale projects.

\section{Interpretations and Conclusions for Successful Utilities}

\section{What every GHP program needs to succeed}

\section{Top level support/involvement/commitment}

All successful utilities have the active involvement and support of top level management. Top level executives take personal responsibility for making sure the entire company understands that they are expected to do whatever it takes to make the program work and produce results. This type of commitment rallies the employees and ensures the program is a success.

Top level commitment is the major distinguishing factor of a successful GHP program. This commitment is demonstrated through personal participation in the program and a focus on results in the marketplace.

\section{Comprehensive knowledge of market development and market development activities.}

Successful utilities take responsibility for market development. Their programs include all basic components of market development, which include a target market, a system for lead generation, a managed sales effort, and an established distribution system.

\section{Aggressive Posture}

Successful utilities realize that the GHP is a replacement product -- you can only sell a GHP by replacing another HVAC product. They do what it takes! 
Utilities can get faster results with a professionally designed program.

PSI \& Consumers Power

These programs demonstrate that if a program is professionally designed and implemented a utility can achieve very significant results within 12 months.

\section{Utilities Can Succeed On Their Own}

Other successful programs demonstrate that utilities can achieve success on their own, without outside expertise. But, due to a lack of marketing knowledge and experience, it will take longer (5-7 years) to achieve the same results. However, by recognizing the marketing challenge in advance, committed utilities should be able to reduce this time period.

Obstacles encountered and solved by successful utilities are the types of obstacles encountered every day by companies in competitive environments.

Utilities can find that competitive "do whatever it takes" attitude -- look at their crisis response teams.

The one situation in which a utility demonstrates the type of personal commitment found in a competitive environment is during a storm or an emergency when peoples' service is at stake. Utilities are personally committed to reliability of service (because their franchise is clearly dependent on this), and do whatever it takes to restore service as soon as possible. This crisis behavior demonstrates they have the ability to perform in a competitive capacity, it's just that they haven't applied this approach to their marketing/sales departments. (Personal actions in a crisis are directly related to results. Success is measured by how fast outages are restored).

\section{Industry Concern}

Three very successful GHP programs were discontinued by the utilities that created them. The reasons vary, but they got caught in the year to year -- "new organization, new program mentality" that afflicted most utilities. This short term approach to marketing undermines the long term potential benefits of marketing. A developed market with paying customers has real dollar value to competitive industry -- you keep it or sell it, its the Golden Goose -- you don't kill it off. 


\section{How Unsuccessful Utilities can Enhance their GHP Programs and Produce Results}

Utilities in this section have committed resources to GHP programs but have not achieved a significant number of installations or market penetration. Some of them appear to have effective parts of the necessary program elements, but there are pieces missing. For instance, one program may have strong market development activities and several people committed to the technology, but no support of top level management. Another utility may have an aggressive attitude but no concept of market development.

The people involved in these programs felt they were successful because they based their evaluations on things other than results in the marketplace. When measured in terms of market share and number of installations, we found that these programs were not successful, but they have the potential to be successful if the utility follows the examples of the successful utilities studied in this report.

In this section we will compare and contrast unsuccessful GHP programs with successful. GHP programs so that utilities may learn by example what it takes to promote and sell GHPs.

\section{Commitment}

\section{Utility A}

Utility A has a base of 200,000 retail customers. Total installations for the past three years were 50 . In terms of market share, this GHP program was not a success.

When we studied this program, we found that this utility has a strong understanding of market development. Its GHP program included the key areas of market development, including target market, lead generation, sales, and distribution.

To increase customer awareness of GHPs and generate leads, the utility had an internal education program for their employees (articles in utility newsletter, handouts and video), definite target markets, and an advertising/promotional campaign that included going to home shows and trade fairs.

To capture leads, this utility had a toll-free 800 number, which was included on all promotional materials. This resulted in over 400 requests for information regarding GHPs. The only drawback was the lack of a single project manager to follow up on all the leads. The duties and sales responsibilities were divided among eight people, so there were more opportunities for potential customers to slip between the cracks. 
To effectively distribute and install GHPs, this utility involved HVAC contractors in its program. The utility provided training and support for the contractors and had a field representative present at loop installations.

Strong market development leads to an aggressive posture, so the utility appeared to have an aggressive position in the marketplace, but the low number of installations indicated there was a key ingredient missing. The utility had no support from top level management.

Another factor leading to the program's failure is the lack of a person to champion the program. The duties of the GHP Program project manager, or champion, were split between eight people, whose total combined time spent on the project equaled one half of one person's time. The program would have had a better chance of success if one person was responsible for performing the duties related to the GHP Program instead of eight. This situation demonstrates that the utility didn't care enough about the program results to assign a project manager or commit human resources.

This utility's GHP Program would greatly benefit if it had the type of personal commitment displayed by East Kentucky Power's management. The CEO of East Kentucky Power installed a GHP in his house and saw the benefits firsthand. He kept track of all the money he saved on his energy bills and reported it to the Board of Directors every month. As a result, he persuaded 14 (of the 18) Board members to install GHPs in their homes. Because of his personal interest in the technology, the entire utility was behind the effort $100 \%$ and the GHP Program achieved great results.

At the employee level, some of East Kentucky's district co-ops offered incentives to employees who wished to purchase and install GHPs for their homes. The utility's management recognized the value of its employees as potential spokespeople for the technology.

\section{Recommendations}

Senior and middle management must be aware of the impact their actions have on the commitment and actions of lower level management. If they do not personally believe in the greatness of the product, they are, in effect, telling lower level management that GHPs are not really as great as they say they are. This illustrates the difference between lip service and genuine commitment on the part of the utility. It also shows a lack of understanding and awareness on the part of senior level management regarding the relationship between their personal attitudes and behaviors and success in the marketplace. 


\section{Market Development -- Cohesive Strategy with Target Market}

\section{Utility B}

Utility B has a commercial customer base of 261,188 and they have had a total number of approximately 175 GHP installations since 1993 . This utility conducted some market development activities that were mildly successful, but they did not understand how those activities worked together to form a cohesive program and produce results. For instance, their lead generation efforts consisted of sending a direct mail postcard to a target audience, but they had no system for capturing leads or following up with customers. People who responded to the postcard were referred to manufacturers for follow-up. Their efforts to involve distributors showed the same pattern -- the utility provided training and support for HVAC contractors but neglected to train or support loop installers.

Through our survey, we found that top level management allocated resources to the program, but is not personally committed to promoting GHPs. Utility management viewed market development as a laundry list of activities from which it could pick and choose. What they do not understand, is that if you leave off an important set of market development activities, you won't get any results.

If Utility B had a cohesive strategy, which included a target market, lead generation, sales and distribution, they would achieve more results.

\section{Market Development -- Lead Generation}

\section{Utility $\mathbf{C}$}

Utility $\mathrm{C}$ has a customer base of 1.1 million. In the seven years it has been conducting a GHP Program, it has only sold 20 units.

The reasons for this utility's lack of success is obvious -- it had no commitment on the part of top level management, very little market development, and no aggressive posture.

Two managers at Utility $\mathrm{C}$ have GHPs in their homes, but there is no personal commitment on the part of top level management. If management is not committed to the program or actively involved in promoting it internally, their actions (or inaction) will lead other employees to believe that investing in such a system is not worth it. This is a primary example of how top level managers pay lip service to promoting GHPs but are not genuinely committed to promoting the technology.

Utility $C$ had no education for employees, no system for lead generation, no advertising, no training or support for HVAC contractors, no involvement for loop installations, no guarantees. It did, however, have a target market (residential) and four marketing/sales representatives who promoted GHPs and participated in the program. 
This utility's attitude can be summed up by their management's philosophy on GHPs -they believe drilling costs are too high for their customers to consider GHPs. Instead of taking active steps to reduce the first-cost price barrier, or influence market forces to bring the cost of GHPs down, this utility takes a passive approach and opts not to market GHPs.

Utility $C$ could enhance their GHP Program by adopting some of the lead generation practices of United Power Association. United Power put in the time and hours to make sales happen. They participated in Home Shows and Home Buyer Workshops and sponsored special events to gain the interest of potential customers. Marketing personnel attended school board meetings to pitch the concept of geothermal heat, involved themselves in all school decisions, and took school board members and superintendents on tours of schools that had GHPs.

Utility personnel worked hard to meet the special needs of their customers. For example, the utility provided the necessary financing to sell a 100 ton GHP system to a furniture store, and hired a consulting engineer to give an objective opinion to a building owner because the owner's own engineer was reluctant to try geothermal heat. This type of commitment is critical to the success of GHP programs.

To help overcome the first cost price barrier, United Power offered low-interest financing to residential and commercial customers and provided incentives for customers and contractors. They also helped develop a slinky loop approach to loop installations to keep prices low.

\section{Market Development -- Sales}

\section{Utility D}

Utility D doesn't have a very targeted GHP Program. One of the people we interviewed stated: "One of our problems is that we do not have a goal and we do not measure our successes against that goal."

The utility does not have a target market and it does not educate its own employees.

Utility D would have more success if they incorporated sales practices from Interstate Power. Interstate has a solid understanding of the GHP market and market development and an excellent relationship with trade allies. Interstate found that the key to closing the sale in the commercial market is "one-to-one" marketing and relationship building. For instance, the Program Manager flew the engineers associated with a potential commercial installation to see a similar GHP operation in Indianapolis. He also flew with engineers to see a GHP operation in Canada. By devoting personal attention, using videos, and bringing engineers to see similar applications of the technology, the Program Manager is able to convince these key people in the importance, feasibility, and benefit of geothermal technology. 


\section{Market Development -- Distribution}

\section{Utility $\mathbf{E}$}

Utility E offered no training or support for HVAC contractors, no involvement for loop installations, and no product guarantees. The utility's management also stated that drilling costs were too high for their customers to consider GHPs.

Instead of taking active steps to reduce the first-cost price barrier, or manipulate market forces to bring the cost of GHPs down, this utility takes a passive approach and opts not to market GHPs. What they should do, is borrow ideas from Ohio Edison.

The success of Ohio Edison's market development activities is due to the fact that they understood the industry and the motivation of the key players (customers, contractors, loop installers). They were actively involved in recruiting and training HVAC contractors and loop installers, and they managed their relationships with trade allies in such a way that they were able to control market forces and keep prices down. 


\section{Interpretations and Conclusions for Unsuccessful Utilities}

There is a wide range of variation among unsuccessful utilities in terms of market development activities. Most utilities in this category conduct a few market development activities, but they don't understand how those activities interrelate. For example, some utilities will put a GHP Program in place but won't initiate a lead generation effort -they'll make information and rebates available, but they won't actively manage the effort. Another utility may be exceptionally good at generating leads but not involve themselves in the sales process. They lose a countless number of sales because they don't have a system for responding to customer inquiries or following through on requests.

Furthermore, utilities in this category tend to measure success on things other than sales or market penetration -- they measure success on how many brochures they created or if they offered incentives.

In some cases, unsuccessful utilities look very much like successful utilities in terms of market development. They conduct all aspects of market development -- lead generation, sales, and distribution -- in some fashion or another, but their programs are still unsuccessful in terms of number of installations and market penetration (per customer base). These cases require some interpretation.

We have found that all unsuccessful utilities lack top level management support. This explains why some utility programs, which include all the necessary market development programs and appear to be aggressive, have poor results. These situations lack top management commitment. These programs will have a verbal commitment from top level management, but this commitment will not carry over in terms of management actions and deeds. When top level management makes a verbal commitment and then puts the responsibility of the program's implementation and success on a lower level project manager, the result is an attitude of indifference on the part of the utility's employees, which can actually undermine the program.

On the other hand, when top level management is actively involved in the program, it becomes a company program. It is clear to the entire utility that this program is a top priority. As a result, everyone understands and supports the program and works to achieve results.

Unsuccessful utilities demonstrate, beyond a shadow of a doubt, that the single most important element to the success of a GHP Program is the active involvement of top level management. When top level executives get involved and want something to happen, it happens. When they remain uninvolved and simply allocate resources to individuals on a lower corporate level, the program does not achieve results

Our case studies provide examples of utilities that have excellent champions supporting their GHP Programs and all the necessary market development elements, but no commitment from the vice president of marketing. The VPs do not involve themselves in 
the programs at all, they do not actively interact with program personnel, they do not take an interest in results, they do not make the program or its results a personal priority. As a result of these actions, everyone between the vice president and the project manager "understands" that GHPs are not that important, so instead of getting behind the program $100 \%$, they actually undermine the program with their lack of cooperation. The program ends up being the pet project of the Project Manager, not a company program. Other middle management people do not support it, other employees do not support it, they're all indifferent to the effort. The lack of involvement of the vice president sends a clear message that he doesn't really care about the program, so neither should they.

\section{Results}

Successfully marketing and selling geothermal heat pumps is not a major difficulty in and of itself -- however, it does present some major challenges to the electric utility industry.

Our study concludes that the factors critical to success are:

- Top management marketing commitment

- An understanding of the fundamentals of marketing and business development

- An aggressive competitive posture 